\title{
Problems of Teaching Economic Disciplines to International Students at a Technical University
}

\author{
Rimma Makmunovna Shaydullina \\ Department of Humanities and Socio-Economic Sciences \\ Ufa State Petroleum Technological University, Branch of the University in the City of Oktyabrsky \\ Oktyabrsky, Republic of Bashkortostan, Russian Federation \\ e-mail: rimmanet58@mail.ru
}

\begin{abstract}
The relevance of this study is caused by the fact that the increasing competition among universities in the international market of educational services, as well as the inclusion of universities in academic ratings, shows a tendency to increase the share of international students studying in Russia. Joint education of Russian and international students has its own specificity, since students with different level of Russian language proficiency and different level of pre-university training are united in groups and cohorts. In these circumstances, without the introduction of new methods and approaches to scientific disciplines, it is impossible to train qualified specialists in accordance with international educational standards. The purpose of the paper is to identify factors influencing the academic adaptation of international students; to search for solutions of joint education tasks at a technical university; to present innovative methods of teaching economic disciplines. The materials of the paper present a practical value in the field of domestic higher education and open the possibilities of applying the used approaches to teach economic disciplines at technical universities within the joint education of Russian and international students.
\end{abstract}

Keywords - international students, academic adaptation, technical university, innovative techniques, economic disciplines.

\section{INTRODUCTION}

The need to increase the competitiveness of Russian universities in the international market of educational services inevitably sets new guidelines for scientific and educational activities of universities that train specialists for foreign countries. The share of international students is one of the most important ranking indicators of the university. Already more than 100 universities in Russia are training specialists in various sectors of the economy. According to Rosstat (Russian statistic agency), in 2018, 260.1 thousand international students studied at Russian universities, including students from CIS countries, the Baltic States, Georgia - 191.6 thousand; Asia and Africa - 63.4 thousand, Europe, the Americas - 4.9 thousand people [1]. Oil and gas universities of the country are also actively involved in the training of international students. In particular, almost 1,300 people from 67 countries are currently studying at Ufa State Petroleum Technological University (USPTU). The Oktyabrsky branch of USPTU (a division of the head university) also trains international students in Oil and Gas Business, and the number of students is increasing. The number and ratio of students who came from CIS countries (Kazakhstan,
Uzbekistan, Tajikistan) and non-CIS states (Africa, Asia) to study in the branch of USPTU are shown in the figure.

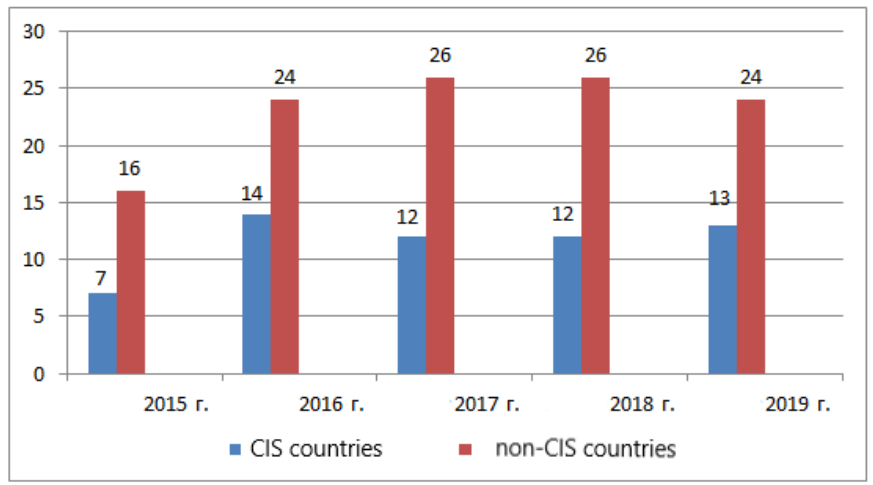

Fig. 1. Number of international students (CIS and non-CIS countries) admitted for the first year of study to the Oktyabrsky branch of USPTU

The share of international students in the total number of students in the branch is also increasing. If in 2017-2018 academic year the share of international students in relation to the total number of second-year students reached $32.45 \%$, in 2018-2019 academic year their share increased to $42.85 \%$, in $2019-2020-37 \%$. This means that more than a third of the students within a group are students from foreign countries.

Under these conditions, the university educational environment becomes specific and is connected with the internationalization educational groups and cohorts. There are new factors influencing the educational process: thus, there are groups of students representing different ethnocultures and religions, different levels of proficiency in Russian, different levels of general education training, since international students come from different countries where there are different educational systems. According to the analysis of scientific and pedagogical literature, the problems of joint education of Russian and international students at Russian universities are not sufficiently developed, complex and at the same time quite relevant [2-4]. The current situation in the system of higher education requires the improvement of scientific and pedagogical resources, use of other, different from traditional, pedagogical methods and means, as well as methodological techniques enriching the content of educational disciplines thus ensuring high quality of professional training. The purpose of the paper is to show various innovative methods and methodological techniques on 
First of all, we found what affected the choice of students the example of teaching Economics at a petroleum university (branch of USPTU in Oktyabrsky), which allow overcoming the above problems of joint education of Russian and international students, promoting academic adaptation of international students to the Russian educational system.

\section{RESULTS AND DISCUSSION}

There is no doubt that the education of international students at Russian universities contributes to the integration of domestic higher schools into the global intellectual space and, therefore, stimulates the development of science and practice in the country [5-7]. But it is impossible to abstract from the problems that the university teachers face when working with international students, namely: students of different religions, ages, speaking different languages, having different training in general educational subjects; students that have poor command of Russian; students experiencing considerable difficulties while studying sufficiently complex special subjects in a non-native language, etc. [8,9]. These factors have a significant influence on the content, forms and methods of organizing the educational process at the university. A new pedagogical system and a different system of training of international groups and cohorts are being formed.

Most of the works of domestic researchers consider the problems of teaching international students at Russian universities in the context of problems and difficulties experienced by international students in adapting to life and study in Russia. Traditionally, there are three types of student adaptation: physiological; socio-cultural, which is caused by changing conditions and often by the quality of life; academic related to new requirements for educational activities. Some researchers further highlight linguistic adaptation (related to linguistic competence), socio-psychological adaptation (as a process of adapting to the conditions of the social environment, mastering its norms, traditions of group culture, entering the role structure of a group $[10,11])$, sociopedagogic (as a wider process of entering the educational environment and mastering its norms, requirements, values [12]). The purpose of this study is to identify problems primarily related to academic adaptation, which includes the adaptation of international students to didactic environment of the petroleum university (curriculum of studied disciplines; class schedule; forms of lectures, seminars, practical classes; types of independent work; forms of knowledge check and verification, forms of knowledge assessment, etc.).

In order to implement the task to identify factors affecting the adaptation to the new educational system, a sociological survey was conducted among international students studying at the Oktyabrsky branch of USPTU. 31 students of the second and third years from non-CIS countries (Iraq, India, Angola, China, Yemen, Egypt) and 13 students from CIS countries (Kazakhstan, Uzbekistan, Tajikistan) participated in the survey. The students from CIS countries were considered within a separate group, which is caused by the fact that they come from the countries of the former Soviet Union, where the traditions of learning Russian in general education schools (at least at the level of a foreign language) are still strong. The survey was conducted in 2018. to receive petroleum profession at the university, what was their motivation for getting education in Russia. The responses are shown in Table 1.

TABLE I. WHAT AFFECTED YOUR CHOICE OF A PETROLEUM ENGINEER?

\begin{tabular}{|l|c|c|}
\hline \multicolumn{1}{|c|}{ Options } & $\begin{array}{c}\text { Non-CIS } \\
\text { students, \% }\end{array}$ & $\begin{array}{c}\text { CIS students, } \\
\text { \% }\end{array}$ \\
\hline $\begin{array}{l}\text { Corresponds to my } \\
\text { abilities }\end{array}$ & 16.1 & 38.5 \\
\hline $\begin{array}{l}\text { Attracted by the content } \\
\text { of future work }\end{array}$ & 19.4 & 38.5 \\
\hline Parents' advice & 19.4 & 7.6 \\
\hline $\begin{array}{l}\text { It is easier to find job in } \\
\text { petroleum industry at } \\
\text { my homeland }\end{array}$ & 12.9 & - \\
\hline $\begin{array}{l}\text { Job in petroleum } \\
\text { industry is highly paid } \\
\text { in my homeland }\end{array}$ & 29.0 & \\
\hline University status & 3.2 & - \\
\hline
\end{tabular}

According to the survey, the students from Asia and Africa are mainly motivated for obtaining a specialty in the field of oil and gas by high remuneration of labor (29\%), significant authority and such factors as "parents' advice" (19.4\%) and "attracted by the content of future work" (19.4\%). For students of CIS countries, the motivation for obtaining this specialty is not related to the possibility of getting a job at home, but is largely determined by the desire to get education specifically in the sphere that attracts them in terms of "labor content" $(38.5 \%)$ and that it "corresponds to abilities" $(38.5 \%)$. In general, the results of the survey show that most students independently decided on the choice of profession and country of study. Moreover, about a third of all international students plan a master's degree as the purpose of their studies in Russia.

The data can be compared to the survey of Russian students [13]. For Russian first-year students in the choice of profession the most significant factor was "parents' advice" $31.7 \%$, which indicates less independence of the Russians in the choice of their future profession.

The adaptation of international students to the new conditions of study and life is a key point that ensures the efficiency of the educational process at the university as a whole. In order to identify problems related to academic was asked: What problems do you face when studying at the university?", and the student could choose several answers important for them. The following results were obtained (Table 2). adaptation of international students, the following question 
TABLE II. WHAT PROBLEMS DO YOU FACE AT THE UNIVERSITY?

\begin{tabular}{|l|c|c|}
\hline \multicolumn{1}{|c|}{ Options } & $\begin{array}{c}\text { Non-CIS } \\
\text { students, \% }\end{array}$ & $\begin{array}{c}\text { CIS students, } \\
\text { \% }\end{array}$ \\
\hline $\begin{array}{l}\text { Poor understanding of teachers' } \\
\text { explanations due to poor } \\
\text { knowledge of the Russian } \\
\text { language }\end{array}$ & 45.2 & 30.4 \\
\hline $\begin{array}{l}\text { Neediness of educational } \\
\text { literature }\end{array}$ & 9.7 & \\
\hline $\begin{array}{l}\text { Complexity of disciplines studied } \\
\text { at the university }\end{array}$ & 29.7 & 3.4 \\
\hline $\begin{array}{l}\text { Problems related to teaching } \\
\text { methodology (difficult to answer } \\
\text { at seminars, unable to perform } \\
\text { homework on my own, high } \\
\text { teacher requirements) }\end{array}$ & 22.6 & 30.7 \\
\hline $\begin{array}{l}\text { Differences in the school system } \\
\text { across countries }\end{array}$ & 48.4 & \\
\hline Different assessment system & 3.2 & \\
\hline
\end{tabular}

The results of the survey show that the academic adaptation of international students from non-CIS countries is predictably influenced by such factors as poor knowledge of the Russian language (45.2\%), methods of learning scientific disciplines and teacher requirements $(22.6 \%)$, as well as differences in general education training (48.4\%). These factors were highlighted by almost all researchers. However, if we compare these data with the data of the survey of students from CIS countries, we can see that for them the methodology of teaching $(30.7 \%)$ and the complexity of disciplines studied at the university $(35.4 \%)$ are more significant.

It should be noted that successful adaptation to the educational process, adaptation to the specifics of education in the Russian university is a guarantee of good academic performance. Therefore, it is necessary to find other pedagogical methods, tools, methodological techniques that differ from traditional ones, which can stimulate educational and cognitive activities of international students and facilitate their adaptation.

By identifying the causes that have a significant impact on academic adaptation, it is necessary to identify the factors that would contribute to eliminating or mitigating the effects of maladjustment of international students. The question What helps you to quicker adapt to the educational environment of the university? implies the assessment of the respondents' opinion on adaptation on a bigger scale, including not only educational adaptation, but also some aspects of socialization in the new environment (Table 3). Students could choose multiple answer options.

The table shows that the students of CIS countries made a bid for academic adaptation (61.5\%) and for the factor contributing to academic adaptation (friendly attitude of teachers $-46.2 \%)$. The students from non-CIS countries emphasized communication with Russian-speaking students (45.2\%) and accommodation in a hostel, improvement of living conditions $(38.7 \%)$. This emphasizes the importance of acquiring language competence first of all and secondly, the difficulties of getting used to real living conditions in Russia.
TABLE III. WHAT HELPS YOU QUICKLER ADAPT TO THE EDUCATIONAL ENVIRONMENT OF THE UNIVERSITY?

\begin{tabular}{|l|c|c|}
\hline \multicolumn{1}{|c|}{ Options } & $\begin{array}{c}\text { Non-CIS } \\
\text { students, \% }\end{array}$ & $\begin{array}{c}\text { CIS students, } \\
\%\end{array}$ \\
\hline $\begin{array}{l}\text { Active participation in training, } \\
\text { reports at seminars, participation } \\
\text { in research activities }\end{array}$ & 16.1 & 61.5 \\
\hline $\begin{array}{l}\text { Friendly attitude of teachers } \\
\text { towards foreign students }\end{array}$ & 38.7 & 46.2 \\
\hline $\begin{array}{l}\text { Development of oral speech skills } \\
\text { in communication with Russian- } \\
\text { speaking students }\end{array}$ & 45.2 & 15.4 \\
\hline $\begin{array}{l}\text { Work experience internship at } \\
\text { Russian enterprises }\end{array}$ & 22.6 & 23.0 \\
\hline $\begin{array}{l}\text { Accommodation in a hostel, } \\
\text { improvement of living conditions }\end{array}$ & 38.7 & 23.0 \\
\hline $\begin{array}{l}\text { Active participation in the } \\
\text { cultural life of the educational } \\
\text { institution and the city }\end{array}$ & 16.1 & 14.7 \\
\hline
\end{tabular}

Thus, the survey of international students studying at the branch of the technical university made it possible to draw the following conclusions:

1) the difficulties of academic and social adaptation are mainly related to an insufficient level of Russian language proficiency;

2) the most problematic for international students is the adaptation to the educational program and teaching methods of scientific disciplines;

3 ) international students are interested in more attention from teachers.

Therefore, the search for new student-based methods of teaching and learning that enhance students' cognitive activity and facilitate their adaptation is becoming relevant.

The pedagogical aspect of adaptation is manifested in the peculiarities of adaptation of individuals to the new pedagogical system, different system of training, multinational composition of groups and cohorts, the need to learn a large flow of information in a non-native language, the formation of new qualitative knowledge and skills. When working in new conditions, when students from different countries, having different language training, different level of school training, different level of culture, habits and lifestyle, are united in groups, the teachers face the problem of complicating the task of developing both universal and professional competences among students. In our opinion, the teacher faces the dilemma "either to focus on the level of training of international students, reducing the level of requirements for training of Russian students, or to pull international students to a higher level of training of Russian students". Undoubtedly, the first way is unacceptable in conditions of increasing competition among universities, both in the international and Russian educational space. Therefore, the difficulties of joint education of Russian and international students can be overcome by developing and implementing special methods and methodological techniques for classroom activities, types of independent work, scientific and research activities, which allow involving international students in the educational process of the technical university in the most effective way. 
The study showed that the most difficult type of speech activity for international students is listening and recording lectures [14]. The teacher also faces such a problem in the study of economic disciplines, especially considering that this subject is not included in the school curriculum, unlike mathematics, physics, chemistry, etc. Difficulties arise, first of all, due to misunderstanding of the terminology field of scientific discipline in a non-native language, inability to work with sources of information, lack of ability to highlight causal relations and key points of received information. These difficulties lead to inefficient assimilation of the lecture material delivered in a traditional form, as students barely understand what the teacher says. Hence, students lose interest in the subject, and their motivation to attend the lectures is lost. These problems can be overcome if other teaching strategies are applied, both in the classroom and for self-study.

The new strategy for the assimilation of Economics by international students at a technical university was based on the principle of "advanced" learning offered by Salman Khan, the creator of the Khan Academy, a free online learning platform [15]. The essence of Khan's experimental study is "flipped learning", when schoolchildren listen to lectures and solve tasks at home, and during the lessons discuss the most difficult issues in the material with the teacher. This approach to studying theoretical material was implemented in the form of preliminary training of international students who do not know Russian well to lecture material. For this purpose, the teacher's lectures were made available both in hard copy and in electronic form. Such study guides as The Economics in Schemes were prepared and published, according to the sections of the discipline. The guide is presented in the form of a summary of theoretical issues of economic theory and structural-logical schemes developed by the author of the course and used in lecture presentations. The value of this guide is that the presentation of logical schemes in the form of graphs, tables, etc., facilitates students' perception of theoretical material, promotes its assimilation and provides substantial assistance in preparing lecture and seminar classes, for examinations and credits. A teacher informs international students in advance about the topic of the forthcoming lecture. A student prepares for a new lecture ahead of schedule thus ensuring preliminary familiarity with economic terms, key points of the lecture content. The progress and quality of the material study are monitored as follows. During home study, a student fills in the "log book", which is handed over to the teacher at the beginning of the lecture (Table 4).

Such "log books" lead to better understanding of the main content of the lecture, as the student has previously familiarized himself with the topic. While listening to the lecture, a student makes notes focusing on issues that were difficult to learn. As a result, it forms note-taking skills of both listened and read material, ability to select and understand basic scientific information. At this stage the task of the teacher is to monitor the process of classroom work on the development of scientific material.
TABLE IV. LOG BOOK FORM

\begin{tabular}{|l|l|}
\hline \multicolumn{2}{|c|}{ LOG BOOK TO CHECK THE QUALITY OF } \\
MATERIAL ASSIMILATION ACCORDING TO \\
ADVANCED LEARNING METHOD
\end{tabular}

The innovative educational technologies recently introduced for modern engineers are aimed at forming competences among university graduates as an integrative quality allowing applying interdisciplinary knowledge and skills in future professional activity. In order to implement this task in the joint training of Russian and international students, we practiced such direction of interdisciplinary integration as the seminars on economics in English. The method of such training is as follows. The issues of the seminar were discussed both in English and Russian. Initially Russian students made their reports in English, while the rest of the students also asked questions on the topic in English. In the future, international students spoke on the same topic already in Russian, and the questions were also asked in Russian. Thus, we achieved the purpose of increasing the interest in studying the economy not only among Russian, but also among international students, who often remain passive at seminar classes due to poor knowledge of the Russian language. International students, for whom English is the second state language, show great interest in seminars in English. The main disadvantage of such a technique is the need for a foreign language teacher to be present in the class and monitor the correctness of speech. However, in our view, such classes should not be held on a weekly basis. During the semester, 1-2 seminars can be focused on the use of this technique. The main purpose of such a class is to involve Russian students in economic texts in a foreign language, and for international students - to intensify their preparation for seminars and to promote the formation of public speech skills in Russian, which is foreign for them.

A big problem for many international students is the lack of independent work skills. Quite often students do not know how to use the library, work with cases, etc. The process of self-education makes it much easier to involve students, including foreigners, in the work in the virtual educational environment MOODLE.

The electronic content on the discipline Economics in the MOODLE virtual learning environment is presented by electronic study guide Economics in Schemes; a tutorial to prepare for workshops; tasks offered to students to monitor the learning of economics, as well as tests on each subject of the curriculum, both for self-monitoring and for monitoring the level of learning by the teacher. All user activity is recorded and monitored by the instructor, and then taken into account in the score-ranking knowledge assessment system. We can master the discipline in MOODLE not only in Russian. 
The educational materials have also been developed in English. The experience showed, international students can work in this system on their own. The tests on the studied material are a mandatory requirement in the system of assessment of knowledge and formed competences in the process of training.

We also used such form of independent work as casetechnologies, involving not only discussion of cases developed by the teacher at seminars, but also the involvement of students themselves in the development of author's cases. Based on the studied event, information, statistical material, the student identifies the problem, develops a list of issues aimed at solving it. The final stage is presentation and defense of the developed case. In our opinion, this form of independent work is very effective to develop students' knowledge and skills in economic disciplines. In order to make the case attractive in content, both to international students and to Russians, the teacher guides students to attract information on the current economic problems of the states from where international students arrived to study in Russia. Case technologies help to develop the competencies of international students such as the ability to establish a link between the situation, the problem and the necessary knowledge in the field of economics, to find a way to solve the problem, to make a decision and to assess its consequences. The development of such competences will ensure the readiness of graduates for effective economic activity in their homeland.

The system of assessment of students' knowledge in economic disciplines plays an important role in educational activities. It should be open and understandable to students and contain uniform requirements for all students. For more objective assessment of the level of knowledge, a scoreranking system is widely used, in which the teacher clearly formulates the types of work of a student, the number of points given for each type of work and the criteria of evaluation. The types of works include: attending lectures, speaking at workshops, working independently in a virtual environment MOODLE, testing the studied material, preparation and defense of cases and projects. The total number of points earned by a student is fixed by the teacher and is available to all students and, eventually, serves to assess knowledge, skills and competences of economic disciplines.

The introduction of new innovative methods into the educational process of the technical university in the study of economic disciplines made it possible to increase the academic performance of international students. Out of 19 international students studying in the field of Petroleum Industry, $36.8 \%$ of students received "excellent", 31.6\% - "good" and 31.6\%"satisfactory". In the previous exam session, about $90 \%$ of students were ranked satisfactory.

The analysis of the study leads to the following conclusions:

- difficulties in joint training of Russian and international students in economic disciplines are caused by significant differences in natural-scientific, humanitarian, linguistic training. This requires university professors to take a differentiated approach to students;
- introduction of new innovative methods of lectures, seminars, case technologies, types of independent work in the electronic educational environment develop motivation of students to study economic disciplines, increase the level of speaking skills, make their answers more meaningful and competent;

- enrichment of the content of economic disciplines with new ideas and educational technologies will soften the process of adaptation of international students to the educational process at the university and will ensure high quality of further training.

\section{CONCLUSION}

Thus, the pedagogical activity of university teachers that train students from different countries has its own specificity. This is caused by the need to study in Russian, to learn the language of the specialty and to adapt to the educational process as a whole. Academic adaptation (as the adaptation of a student to a new pedagogical system) means the adaptation of international students to the peculiarities of the educational process at a Russian university, to the methods of teaching, to the need to learn a large volume of knowledge, analyze scientific material. The problems of academic adaptation of technical students provide for the need to find such content, forms, and methods of educational activity, by means of which the universities teachers could mitigate and eliminate negative consequences of maladjustment, improve academic performance of international students in order to successfully develop the required professional competences.

\section{References}

[1] Federal state statistics service. Retrieved from: https://www.gks.ru/free_doc/doc_2018/year/year18.pdf

[2] L.Z. Samigullina, "Some Aspects of Cognitive and Ideographic Characteristics as a Means of Professional Terminological System Description" European Research Studies Journal vol. XVIII. Iss. 4. pp. 197-210. 2015.

[3] E.L. Guseinova, "Organizational and pedagogical conditions for the development of professional competencies in the technical students' individual work through the example of studying the discipline «Hydraulics and fluid mechanics»" European Journal of Contemporary Education. vol. 7. iss 1.pp. 118-126. 2018

[4] E.A. Mukhtasarova "State of modern Russian youth tolerance" European Proceedings of Social and Behavioural Sciences vol. 50. pp. 206-213 April 2018. (RPTSS 2018 - international conference on research paradigms transformation in social sciences, p.1464, 2018)

[5] R.R. Shangareev, "Role of employee motivation in an industrial occupational risk management system" Mechanical engineering vol. 194. No 2. pp. 1-7. October 2018 (IPDME2018, 2018)

[6] K.F. Gabdrakhmanova, "The way of using geothermal resources for generating electric energy in wells at a late stage of operation" Mining and exploration of mineral resource Vol. 194. No 8. pp. 1-9. October 2018 (IPDME2018, 2018)

[7] K.F Gabdrakhmanova, "Nomogram method as means for resource potential efficiency predicative aid of petrothermal energy" Journal of Physics: Conference Series. vol. 1015. No 3. pp. 1-5. April 2018 (International Conference Information Technologies in Business and Industry 2018, 2018 )

[8] O.V. Danilova "Peculiarities of Forming General Cultural Competences in Students of Institutions of Higher Technical Education by Means of Interdisciplinary Integration" SHS Web of Conferences, vol. 50. pp. 1-5 October 2018 (CILDIAH-2018, 2018). 
envelopment analysis,” Economic Modelling, vol. 30, pp. 623-635, 2013 DOI: 10.1016/j.econmod.2012.10.016

[13] R.M. Shaidullina, A.F. Amirov, V.Sh. Muhametshin and K.T Tyncherov, "Designing economic socialization system in the educational process of technological university," European Journal of Contemporary Education, vol. 6, no. 1, pp. 149-158, 2017 DOI: 10.13187/ejced.2017.1.149

[14] J. Hou, P.P. Walsh and J. Zhang, "The dynamics of Human Development Index," Social Science Journal, no. 52(3), pp. 331-347, 2015

[15] K. Schwartz How Are Theachers And Students Using Khan Academy Retrieved from: https://www.kqed.org/mindshift/35412/how-areteachers-and-students-using-khan-academy

[12] S. Blancard and J.F. Hoarau, "A new sustainable human development indicator for small island developing states: a reappraisal from data 